\title{
Do the suburbs exist? Discovering complexity and specificity in suburban built form
}

This is a pre-publication version of a paper to be published in Transactions of the Institute of British Geographers in October 2009. Authors: Laura Vaughan, ${ }^{1}$ Sam Griffiths, ${ }^{1}$ Mordechai (Muki) Haklay ${ }^{2}$ and Catherine (Kate) Emma Jones ${ }^{2}$ ${ }^{1}$ The Bartlett School of Graduate Studies, University College London, 1-19 Torrington Place, London, WC1E 7HB.

${ }^{2}$ Department of Civil, Environmental and Geomatic Engineering, University College London, Gower Street, London, WC1E 6BT. Tel. +44 (0)20 76794188 Fax + 44 (0)207 9161887. www.sstc.ucl.ac.uk

\begin{abstract}
In human geography cities are routinely acknowledged as complex and dynamic built environments. This description is rarely extended to the suburbs, which are generally regarded as epiphenomena of the urbs and therefore of little intrinsic theoretical interest in themselves. This article presents a detailed critique of this widely held assumption by showing how the idea of 'the suburban' as an essentially non-problematic domain has been perpetuated from a range of contrasting disciplinary perspectives, including those which directly address suburban subject matter. The result has been that attempts to articulate the complex social possibilities of suburban space are easily caught between theories of urbanisation that are insensitive to suburban specificity and competing representations of the suburb that rarely move beyond the culturally specific to consider their generic significance. This article proposes that the development of a distinctively suburban theory would help to undermine onedimensional approaches to the built environment, by focusing on the relationship between social organisation and the dynamics of emergent built form.
\end{abstract}

\section{Keywords}

England, suburban theory, built environment, emergent, temporal, spatial

\section{Introduction}

The question of 'whether the suburbs exist' is posed rhetorically but not facetiously. An increasingly vast academic literature across a wide range of fields strongly suggests that they do indeed exist, and it is probably true to say that there are few people in the developed world who would not claim to know a suburb when they saw one. If further reassurance were needed it can be found statistically: for example by 2000 the UK had $84 \%$ and the US (on a narrower definition) $50 \%$ of its population classified as resident in suburbs according to government data (ITC 2004; Pacione 2005, 87). The pertinence of the question then, is not metaphysical; we are content with widespread scholarly and common-sense agreement that suburbs are characteristic aspects of the built environment. Rather, it is intended to draw attention to the epistemological fragility of the term 'suburb'. Beyond the most perfunctory level of definition, it is far from clear as to what this term actually means or indeed, whether it can be thought to possess meaning at all. A pronounced tendency to neologism in suburban studies highlights the underlying theoretical weakness. This justifies the original question: if there is widespread agreement that suburbs exist, a fog of competing representations tends to obstruct the possibility of meaningful generalisation. All too often it seems as though the language of the suburban floats free from the suburban built environment. This dislocation means that a particular focus on the suburbs can appear as a distraction, rather than an essential bearing, for research into the relationship of the built environment with everyday social practices. Given the ubiquity of suburban living in contemporary society this seems an undesirable state of affairs.

Although the phenomenon of suburbanisation now extends world-wide, it can fairly be said that its contemporary origins lie in the UK, North-America and Australia. It makes sense therefore, that the academic literature which provides the basis for the critique advanced in this article is drawn from the English-speaking countries where suburban topics have generated the most debate. This emphasis should not obscure the wider aim, which is to contribute to the development of suburban studies as a coherent research domain in human geography. ${ }^{1}$

\footnotetext{
${ }^{1}$ This process has already started with the establishment of the Centre for Suburban Studies at Kingston University and with various projects around the world, such as the 'Re-imagining the Australian Suburb' project at RMIT University, Melbourne, Australia.
} 
Consequently, this article takes the specificity of suburban space and the complexity of its historical development as its starting points. Acknowledging the great variety of ways in which the suburbs have been addressed in the academic literature means challenging in a more fundamental sense conventional descriptions of the urban fringe as tabula rasa. After all, the suburbs are not a recent innovation. The stone carving of the ancient Persian city of Madaktu (Figure 1) clearly shows suburban domiciles situated among the palm trees outside the city walls. ${ }^{2}$ Peter Ackroyd has also commented of London's suburbs that they are "as old as the city itself” (Ackroyd 2000, 727).

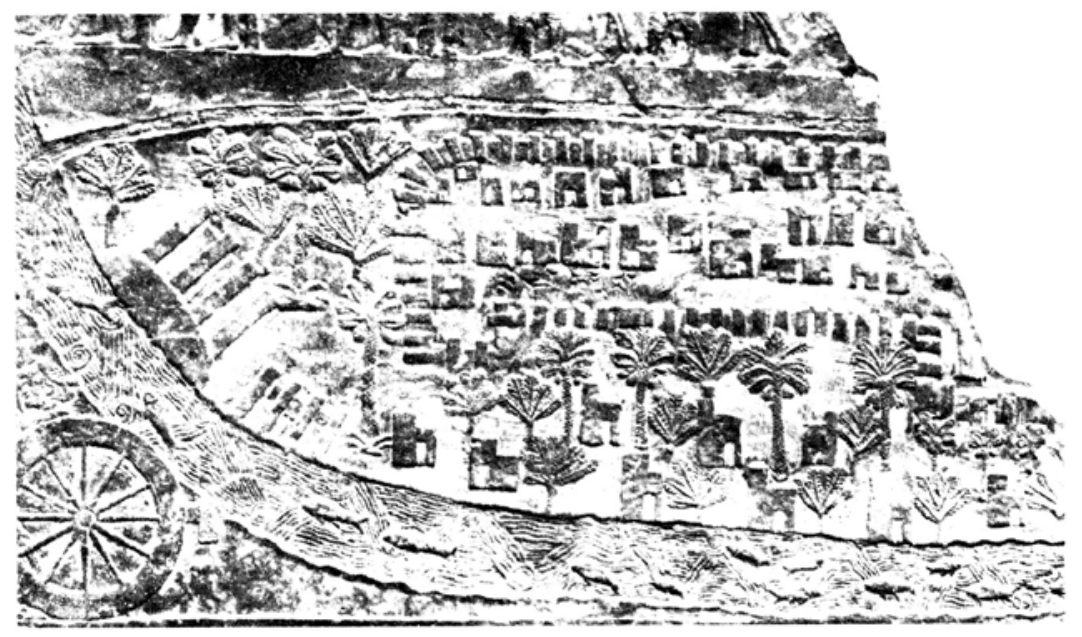

Figure 1: Elamite city of Madaktu. Relief from the palace of Assurbanipal, 668 - 627 at Kunyunji (figure reproduced by kind permission of George Braziller, New York from: Lampl 1968. Cities and Planning in the Ancient Near East. Image credit: Mansell Collection.

We propose that the key theoretical significance of suburban space lies in its potential to undermine dominant historical-geographical narratives of city and periphery, premised on a series of fixed, culturally specific, representations, by successfully articulating the dynamic spatio-temporal principle through which built environments become differentiated and adapt to changing socio-economic conditions over time. Massey (2005) argues that space is constitutive of inter-connected and open-ended space-time trajectories of social relations. From an architectural perspective Hillier contends that the built environment can be approached as the social domain or 'prism' through which such configurations become intelligible to situated human agents (Hillier and Netto 2002). By approaching the organisation of the suburban built environment from this broad 'socio-spatial' perspective, it is possible to consider how a generic but not over-determining description of suburban built form might serve as a prelude to the development of a more effective theorisation of the suburbs; one articulated in terms of the relationship between the emergence of suburban space in particular socio-cultural contexts and the range of social practices that are reproduced there (or are not) over time. To explore this proposition further, this article reviews a wide range of research into suburban subjects in order to examine the different ways in which the relationship between suburban space and society has been represented in the literature. Four such 'suburban imaginations' are identified which are then discussed in the following sections. The article concludes by calling for a reimagining of the suburb as a distinctively dynamic domain in emergent patterns of social organisation.

\section{Imaginations of Suburban space}

Definitions of the suburbs abound in the academic and policy literature. However, these provide little indication as to how the suburban built environment should be approached conceptually as a particular category of inhabited space. In a review of suburban literature, Hinchcliffe has argued:

The literature on suburbs is extensive, yet the subject always seems elusive. For some the suburb is a geographical space; for others, a cultural form; while for others still it is a state of mind. (Hinchcliffe 2005, 899)

Hinchcliffe's observation echoes Connell $(1974,78)$ who criticised the "elusive" and "partial" nature of definitions. In a similar vein, Nicolaides and Wiese $(2006,7)$ argue that, when it comes to defining the suburbs, "consensus seems unlikely to emerge any time soon". While it is, of course, the case that the quest for definitions of urban environments can prove no less contentious, it is the sense of suburban space as peculiarly intangible that emerges

\footnotetext{
${ }^{2}$ We are grateful to Professor Bill Hillier for bringing this picture to our attention.
} 
from the literature. When Hubbard $(2006,7)$ argues for a "reassertion" of the urban he is making the valid point that urban specificity is frequently undervalued in geographical theory but it could hardly be claimed that the subject of the city is 'elusive' in the sense Hinchcliffe uses this term. The reason perhaps lies in the origins of urban centrality at critical historical-geographical nexus, meaning the city occupies the privileged analytical position, thereby extending conceptually the simple geographical sense in which the suburb is 'decentred'.

Four tacit assumptions that inform much of the historical and geographical literature serve to obstruct a fuller conceptualisation of suburban space. The first is a general sense that the 'suburb' is a straightforward geographical concept that ought not to be problematised; this we refer to as the assumption of the 'one-dimensional' suburb. The second is a tendency for the suburb to be conceptualised teleologically as a derivative of the linear urbanisationsuburbanisation process which 'produced' it, regardless of the suburb's own history of spatial transformation as a settlement in its own right. The third is the belief that, as a powerful site of social reproduction, suburban space is adequately described normatively in terms of its multiple cultural constructions. Such culturally based approaches are often accompanied by the implication (tacit or otherwise) that a focus on the specificity of built form is reductive environmental determinism. The fourth engages with the suburban domain as a powerful geographical imaginary of 'otherness' projected beyond the social mainstream where a range of indeterminate social futures may be positioned. The accumulative effect of these assumptions is that the alleged elusiveness of suburbs becomes self-fulfilling. The inhabited space of the suburban built environment itself seems insubstantial in comparison to the weight of geographical representations that it bears. It is argued that this under-theorisation and over-representation of suburban space has effectively deproblematised the suburb in urban theory. The following four sections discuss this proposition in further detail.

\section{The one-dimensional suburb}

The majority of British based studies tend to define suburbs according to a range of planning, socio-economic or cultural criteria. Thorns (1972) differentiates between suburbs according to social class, land use and development type; whilst Gwilliam et al (1999) find it useful to distinguish by dominant mode of transport. More comprehensively Bourne (1996) identifies ten different perspectives on the suburbanisation process, from an expression of rural nostalgia to the 'rational' outcome of developers' preference for cheap land and consumers' preference for a suburban lifestyle. While these systems of suburban classification go some way to recognising the range of suburban built environments and their cultural positioning, they are unsatisfactory in the sense that most actual suburbs invariably contain elements that cut across many of the categories they describe. Such schemes seem to bear limited, or very reductive, relation to actual places. All too often the suburb is assumed to be one-dimensional in comparison with the city.

A powerful tradition in western thought defines the city in terms of the rural world it appears to negate (Williams 1975). In North America the notion of the suburb may also imply a distinct community identity associated with a specific spatial district often embodied in local governments (Harris and Larkham 1999, 14). Whether the contrast is viewed positively or negatively, the sheer scope and depth of work exploring the specificity of the urban experience in human society demands that the complex, multi-faceted nature of city life does not go unacknowledged meaning there is less urgency to resolve underlying theoretical difficulties about the relationship of society and space. However, when the subject being addressed is specifically suburban, this theoretical difficulty becomes more pronounced, since it reveals the absence of a general agreement about specifically what kind of space, if any, is actually at issue. ${ }^{3}$ The geographical transition from the urban nucleus to rural patterns of settlement is relative and variegated rather than absolute, especially in the case of the radically decentralised regions (Sieverts 2003; Marshall 2006). Recognising this fact, scholars have generally preferred to adopt functional definitions of the suburb that are adequate for the task at hand despite having little theoretical value. The difficulty is that such definitions have proliferated but without challenging conceptually the 'common-sense' assumption that the suburban space is essentially a one-dimensional domain that, one way or another, can be reduced to a simple working definition. For example, in 1961 Dyos advanced the notion that:

In essence, a suburb is a decentralized part of a city with which it is inseparably linked by certain economic and social ties. (Dyos 1977, 22)

This definition would still be widely accepted as a description of the most basic properties of traditional suburban settlements (Connell 1974, Hinchcliffe 2005, Pacione 2005, 674). The difficulty is that it clearly assumes the fundamentally residential nature of the suburb and its dependence on the city. Yet long before the accelerated

\footnotetext{
${ }^{3}$ It is a case in point that the numerous introductions to rural and urban geography have few equivalents in suburban studies
} 
decentralisation of employment to what Garreau (1992) has termed 'edge city', suburbs had always served as places of work, especially where the pollution caused by industry or cost of urban space recommended a peripheral location. Contemporary patterns of industrial suburbanisation were well under way in North American cities by the late nineteenth century (Harris and Lewis 2001). More recently, analysis of commuting data from the 2001 census clearly shows the extent of commuter inflows into even relatively small suburban centres in London (SSTC 200609). These commuting patterns suggest that suburban centres are situated in a network of relationships with other places, rather than solely in a bi-lateral relation with the metropolitan centre (see also Masucci and Rogers 2008).

Most contemporary surveys of suburban history and geography explicitly reject any attempt at authoritative definition. Bourne (1996, 163-4) argues for an acceptance of "pluralism in research" in recognition of the "diversity of perspectives" that exists. The comprehensive survey of suburban research by Harris and Larkham $(1999,20)$ also proclaims a multidisciplinary approach as a hallmark of the subject area, highlighting the "surprising complexity of the topic". Similarly, Nicolaides and Wiese $(2006,8)$ celebrate the multiplicity of suburban definitions as a "virtue" rather than a problem. Certainly, it is proper that the extent of scholarly activity in suburban studies since the 1950s should lead to an acknowledgment of the breadth and depth of the research in this area. However, rejecting orthodoxy in definition does not obviate the need for a more substantive theoretical notion of what constitutes the suburban; on the contrary what Bourne refers to as the "increasing complexity and inherent contradictions" of the subject area suggests just why such a theoretical engagement is required (Bourne 1996, 164). In its absence, attempts to approach the suburban as a general research domain are consistently undermined by definitions derived from the particular geographical, social-economic, technological or cultural characteristics that recommend them at a given time. Such a model does not make adequate allowance for the diversity of existing suburbs or for the multiple social possibilities of their future evolution.

Research which focuses on the characteristics of the suburban built environment meets with a recurrent challenge in the literature, in the tendency for suburban space itself to be tacitly 'dematerialised' when considered conceptually. In his classic urban history of the London suburb of Camberwell, Dyos (1977 (Nicolaides and Wiese)) notes how changes in demographics, building legislation and urban development mean that what appears urban in one period or culture, may appear relatively suburban in another and vice versa. He quotes Defoe's description of early eighteenth-century Epsom to make the point that this settlement functioned as spa, market town and commuter outpost of London all at the same time and that suburban boundaries could therefore be blurred by changing transport technology and seasonal patterns (ibid, 26-7). It is notable that Dyos' wish to identify "essential" or "true" suburban characteristics at a conceptual level, repeatedly conflicts with his historical knowledge of London's suburbs, undermining his attempts at straightforward classification. Ultimately, the difficulty of establishing a satisfactory geographical definition leads Dyos to prefer a more amorphous category based upon attitudes and behaviours.

...the modern suburb is clearly less of a geographical expression than it is an attitude of mind and a species of social as well as economic behaviour (26)

Many authors since have come to similar conclusions in viewing the suburb mainly through a primary interest in particular socio-economic or cultural processes, rather than in suburban places themselves - a point recognised by Harris $(1996,18 ; 2004,13)$. Accounts of suburbanisation in terms of race are particularly prominent in the American literature. For example, the intimate relationship between the suburb, the inner-city and its slums, was characterised in post-war United States in terms of 'white flight' from the inner city and an increase in racial segregation (Kruse 2005; Massey and Denton 1993). Widespread academic interest in this process contributed to the construction of a powerful image of the traditional American suburb as white, wealthy and middle class (Fishman 1987; Jackson 1985). This stereotype has since been revealed as just one among diverse suburban identities in which the working class, as well as immigrant and non-white populations, feature strongly (Harris 1996; Nicolaides 2002; Wiese 2004). In a British context Clapson (2003) and Phillips et al (2007) have emphasised the distinctive suburban experience of ethnic minorities. A recurrent theme in both British and American literature is the role of the suburb in defining social aspiration amongst different social groups. Studies of earlier periods in cities including Brussels and London, have also shown how suburbanisation promised a solution to the perceived problem of the concentration of the urban poor (Polasky 2001; Young and Willmott, 1957). The powerful critique of stereotyped representations of 'typical' suburban demography offered by this research is undoubted, yet there is still a need for greater theoretical clarity as to the role of spatial form in influencing dynamics of social change and reproduction in suburbs over time.

Since Dyos many urban historians and historical geographers have considered the particular complexity of suburban built environments (Warner 1978 \{original 1962\}), Jackson 1973; Johnson 1974; Carter 1983, 130-148; Stilgoe 1989; Dennis 2008, 179-205). The historical work of Kelly (1993) on the rebuilding of Levittown and Archer's architectural perspective (2005) on the suburban 'dream house' are comparatively unusual in directly addressing the potential of suburban built form to adapt over time in relation to the development of communal and individual identities in a suburban context. The most systematic contribution in this respect has been made by urban 
morphologists working in the tradition of Conzenian plan analysis (Conzen 1960). Whitehand's subsequent work on the suburban fringe belt has revealed how the distinctive structuring of suburban space is related to building cycle periods. During economic downturns large areas of land on the urban periphery remain relatively undeveloped as land uses are assigned to institutional or recreational use; subsequent development then 'leapfrogs' the fringe belt (Whitehand and Morton 2003). At the scale of the individual suburb Whitehand and colleagues have shown how suburban growth is negotiated through the economic cycle between the state, planners, architects, developers and the owners of individual residences (Whitehand, Larkham and Jones 1992; Whitehand and Carr 2001). Far from being the timeless retreats of the Arcadian imagination, the suburbs of Birmingham are shown to be evolving over time in response to a wide range of factors, including society itself.

Yet the wider significance of research into the social morphology of the suburban built environment is undermined where the theoretical implications of Dyos' argument that the suburb is less of a geographical than socio-economic or psychological entity, is still commonly accepted at face value. Silverstone's $(1997,13)$ discussion of the "suburban imaginary" suggests how the suburban cultural domain risks becoming increasingly detached from the everyday experience of suburban space itself. Silverstone argues that globalisation has had the effect of marginalising ordinary everyday suburban spaces. Yet in a manner similar to Dyos, his response to the theoretical problem presented by suburban space is to accept its dematerialisation within a socio-cultural discourse in which "suburbia is a state of mind", ubiquitous and pervasive; no longer an actual space but a "virtual space" (ibid.).

The theories of Lefebvre (1991 [original \{1974\}), Harvey (1989) and Soja (1990) have contributed significantly to our understanding of how social systems produce space in their image. However, other scholars in human geography have tended to emphasise the importance of space itself as a factor in society's organisation, for example in mediating the conditions through which information is disseminated (Hägerstrand 1967;1982; Pred 1990) and everyday social interaction becomes implicated in the reproduction of social structures (Giddens 1984). In a development of Giddens' theory, Hillier (2008) has argued that there is a tendency in social theory to prioritise the social production of space at the cost of a fuller consideration of the fundamentally spatial nature of human social organisation. The effect is that the built (or otherwise inhabited) environment is reduced to being a simply a passive stage on which society is enacted. The pervasive nature of this assumption is indicated in the introduction to $A$ Suburbs Reader edited by Nicolaides and Weise (2006) in which suburban space is twice referred to as a "backdrop" $(1,6)$. Taking issue with this approach, Hubbard (2006 7) argues that there is a need to take spatiality "seriously" if the contribution of the urban built environment to geographical theory is to be understood. Such seriousness would involve acknowledging the suburb as particular kind of locale in which a multiplicity of socio-economic processes and cultural identities are contested and negotiated over time.

The morphological approach has demonstrated the contribution it can make, not only to identifying the distinctive configuration of suburban built form but also to how this form adapts over time to different social, cultural and economic contexts. However, we propose that a further theoretical-methodological step is required to balance the emphasis on deliberate interventions in suburban morphology to acknowledge the significance of everyday social practices in this adaptive process. Where this dialogue between society and space is insufficiently understood theoretically, the range of competing suburban definitions available seems unlikely to lead to an enhanced understanding of the specificity and complexity of suburban places. The consequence, as Harris and Larkham (1998, 8) have argued, is that the term 'suburb', like the suburbs themselves, "often seems formless" because "to most people, suburbs are characterised along more than one dimension". This point has been noted by the historians McManus and Ethington (2007) who draw on morphological approaches to argue for an "interactive ecology" of suburban built environments and the life-cycles of different suburban communities. McManus and Ethington's belief that suburban history needs to focus on the processes through which suburban life adapts to changing sociocultural dynamics over time complements the case for a distinctively suburban theory of social organisation that is advanced in this paper. To conceive of suburbs as multi-dimensional is to recognise their complexity as social spaces beyond the reductive categories so frequently applied to them, whether in terms of socio-economic processes or exclusive cultural affiliation.

\section{Urbanisation-suburbanisation teleology}

The assumption of suburban one-dimensionality is deep-seated and perpetuates itself in a variety of ways. One recurrent theme or 'narrative' is that of a totalising urbanisation-suburbanisation process in which suburbs are the derivative output [or "excrescence", as Silverstone $(1997,4)$ puts it], of urban development. This process can involve both centripetal suburban development at the urban fringe or centrifugal dispersion of urban activities over a wider area, both are conceptualised relative to the urban centre. Suburban growth trajectories have traditionally been described negatively, in terms of the "assault", "conquest" and "invasion" of the country by the city (Dyos 1977, 31, 33 passim). Mumford $(1940,472)$ gave expressive voice to this discourse in which suburbs are contaminated and 
ultimately destroyed by the "spreading mass" of the devouring city. Within this teleology the possibility for suburban space to sustain difference - its own sources of meaning - are diminished by being reduced to a point in the trajectory of the urbanisation cycle.

The historical relationship of the suburb to the city is evidently key, but the privileged point of view is inevitably urban. One consequence is the imposition of a powerful narrative of 'rise and fall' on the history of the suburb in which the latter is denied agency except in terms of the relative proximity or distance of the city. To historians of English suburbs such as Dyos (Camberwell - London), Cannadine (Edgbaston - Birmingham) and Spiers (Victoria Park - Manchester) it seems that the 'golden age' of the suburb existed from the early to mid-nineteenth century when the cost of transport meant suburban development could be socially exclusive (Dyos 1977 ; Cannadine 1977; Spiers 1976). Dyos argues that by the end of the nineteenth century, with increasing densification of both people and buildings "the great days of Camberwell as a suburb were over" (Dyos 1977, 193). In a similar vein, Nicolaides (2002) has documented how the desire for suburban exclusivity led residents of working-class suburbs in Los Angeles to fear the arrival of urban nuisances such as dirty industry, juvenile delinquents and transient renters that threatened their expectations of the suburban 'good life'. The fear of their suburban neighbourhood going "down in the world" is a staple theme in English culture, expressed recently in fears of suburban "degentrification" (The Daily Telegraph 2006). Currently the narrative of suburban decline and fall is unfolding in reverse in North America where it is distance, rather than proximity, to the urban centre that seems to threaten the suburban way of life (The Guardian 2008a).

If, as this article has argued, suburban space represents the possibility of persistence in time-space differentiation and the pervasiveness of diverse activities within an extended urban region, it follows that the 'urbanisation' of a suburb should not be regarded as synonymous with the total erasure of its suburban identity. The densification associated with 'urbanisation' is often accompanied by the persistence of village-like elements characteristic of the earlier phases of growth; Connell (1974) refers to these as "metropolitan villages". Similarly, elements of suburban morphology, for example their nucleation on pre-urban road networks, often anticipated their later identity as a 'suburban' settlement (Griffiths 2009). In this respect there is some ambiguity in Bourne's statement that:

...the attributes of suburbs that we want to emphasize [are] their relative newness, separateness and location. It is also suggestive of the obvious but often overlooked fact that suburbs are evolutionary or transitional states: yesterday's new suburbs are today's mature suburbs and tomorrow's older suburbs or inner city. (Bourne 1996, 165)

While Bourne notes the adaptability of suburban space he also implies this quality means it is ephemeral since, as suburbs cease to be 'new' or 'separate', they seem to become less 'suburban'. Yet many suburbs have their own histories within a geographical region that, while not ignoring the urban perspective, should not privilege it uncritically. The narrative of suburban rise and fall endorses representations of the suburb as essentially indistinguishable from the history of the city.

This perspective on the suburban as essentially devoid of form is consistent with the schematic models of urban structure provided by the Chicago School in which the more affluent sections of the population are said to move outward through a series of transitional zones projected onto an undifferentiated spatial surface (Burgess 1967 \{original 1925\}). Similarly, the 'black box' perspective on regional urban systems proposed by central place theory arranges centres on the basis of a mechanical scheme with little regard for historically embedded patterns of regional intra-accessibility. To illustrate this point Figure 2 provides a representation of London's suburbanisation taken from the 1969 Greater London Development Plan. The approximate differentiation of the built environment according to development phases is usefully provided by the temporal banding, but the overall impression is of an explosion of matter moving from centre to edge to fill a spatial vacuum. 


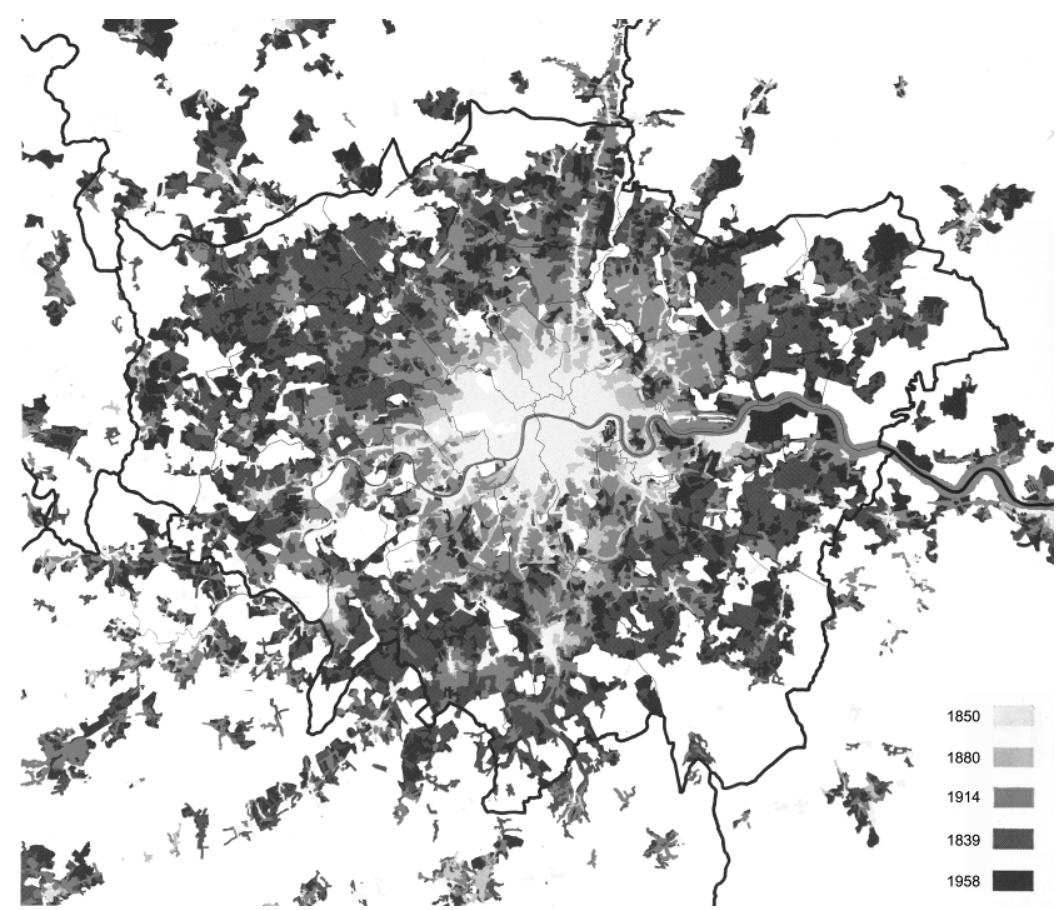

Figure 2: London's suburban growth projected onto a blank surface. Source: Greater London Development Plan Report of Studies. London, Greater London Council, 1969. With the permission of City of London, London Metropolitan Archives.

Non-monocentric models of urbanisation provide alternative conceptualisations of the relationship of city and suburb. Harris and Lewis (2001) have shown how, in North America, some multinucleated suburban regions have nineteenth-century origins as employment locations. Subsequent post-war urban decentralisation was precipitated by the profound effects of mass car ownership, de-industrialisation and advanced communications technologies on the economies of traditional urban concentrations. Castells has said of this process:

...it relies on the formation of relatively dense business and commercial sub-centres, transforming the metropolitan areas into multinuclear, multifunctional spatial structures, organized around ... new "urban villages." (Castells 1989, 156-53)

Recognising this transformation Marshall has argued for a non-hierarchical view of suburban centres since the "the urban gravitational pull is more truly said to be from everywhere to everywhere else" (Marshall 2006, 274). He prefers the term "semi-urban" to 'suburb' as being more appropriate for this multi-nucleated built environment suggesting how, even in a polycentric system, suburban space remains essentially formless, defined negatively in terms of its urban or rural characteristics. Moreover, current approaches to polycentricity tend to be principally concerned with the organisation of major centres into mega-city regions (Hall and Pain 2006); these are hardly concerned with the question of suburban space as such. Sieverts (2003) comes closer to capturing the complexity of extended decentralised built environments in the regions he calls Zwichenstadt. He argues that the privileging of urban centrality is an unhelpful barrier to innovative thinking about diffuse patterns of settlement in which rural and urban forms become increasingly intermingled.

Indeed, the one-sided love for the historical city is the main reason for our repression of the challenge presented by unloved suburbia (17)

Sieverts' contention that the suburbs are unloved can be easily refuted by the extensive literature on its 'loveliness'. This article does not seek to promote either the 'unloveliness' or the 'loveliness' of suburbia but instead to overcome the notion that suburban space must be defined negatively as being neither urban nor rural.

\section{Self-referential multiplicity}

Cultural geographers and literary scholars have, in many ways, been more successful in establishing the suburbs as important loci of socio-cultural identity (Goldsworthy 2005; Archer 2005; Webster 2000; Silverstone 1997). To give one example, the suburb is widely recognised as a highly significant domain for women's engagement with urban modernity (Giles 2004; Marsh 1990). However, theoretical difficulties arise when making the connection back from 
the cultural representation of the suburbs in terms of a particular social group to the materiality of the suburban built environment. Such a connection is necessary to prevent a powerful cultural representation - for example, that of the 'feminine domestic sphere' - becoming clichéd when projected uncritically onto suburban space; this would risk eliding the differences in women's experiences, such as those of the housewife and her domestic help. The absence of a more generic conceptualisation of suburban space means that contrasting normative positions cannot easily acknowledge their essential openness and mutability.

The consequence, it is argued, has been the entrenchment of an assumption of 'self-referential multiplicity' in cultural representation. This refers to the tendency among researchers in suburban studies to imply that the sheer range of perspectives and case studies available to them somehow constitutes a theoretical position in itself. This assumption confuses genuine multiplicity in suburban space with disciplinary fragmentation; whereas the former acknowledges at a theoretical level the interrelation of diverse suburban cultures over time, mediated through social practice in suburban space, the latter sustains a range of insulated representations which remain essentially selfcontained. A wide range of contrasting normative categories of the suburban can be identified within this body of literature, three of which - the dystopian suburb, the realist suburb and the idealist suburb - are discussed below.

\section{The dystopian suburb}

Suburban dystopian theorists are likely to be urban-rural idealists. In other words they believe the suburban to be synonymous with the degradation of the city, the loss of the rural and a challenge to civilised society.

Suburbanisation in England in the second half of the nineteenth century was experienced as trauma by the cultural elite, typified by John Ruskin, who were horrified by the terraces of monotonous suburban housing they believed to be literally and figuratively philistine (Hapgood 2005). More recently Hunt (2004) argues in this tradition that the growth of suburbia in the UK was implicated in the decline of Victorian civic pride.

To McLuhan (1951) and Whyte (1956) writing in post-war America, the suburbs of this period were places of consumerist inspired social conformity. The long commute and low densities associated with 'sprawl' are widely credited with the demise of community life (Riesman 1950; Putnam 2000; Duany et al 2000). Harris (2004) has characterised the same post-war period in Canada in terms of "creeping conformity". In Britain the tone was set by Young and Willmott's (1957) classic comparative study of working class community in Bethnal Green in which the dispersal of an inner-city population to life on a suburban estate is portrayed as destructive of traditional communal structures. Harvey $(1989,122)$ has characterised suburbanisation as the means by which capitalism ensures a market for consumer products and the nourishment of an anti-communitarian ideology of "competitive individualism". The value and integrity of this research is not disputed as much as the ease with which such representations come to be considered as axiomatically suburban.

The representation of suburban space in terms of communal atrophy is associated with an assumption of its essential formlessness. In 1955 Ian Nairn, edited a special issue of “Architectural Review” entitled 'Outrage' to rail against:

...the creeping mildew that already circumscribes all of our towns. This death by slow decay is called subtopia...the world of universal low-density mess. (Nairn, 1955, 365)

Nairn's anti-sprawl polemic, along with his 'Counter-Attack Against Subtopia' (1956) can be highlighted as the precursor to modern anti-suburbanism (Bullard et al 2000); the sober 'post-modern' re-examination of suburbia (importantly in the work of Anderson et al in Australia, 2006); polemics against community decline, and ultimately as the substantiation of the contemporary celebration of urban densification, now seen as the standard remedy to sprawl (e.g. Urban Taskforce 2005). The point here is not the legitimacy or otherwise of the dystopian view. Rather it is to argue that representations in these terms are easily divorced from the historical realities of the suburbs as inhabited space and instead become fixated on the symbolic value of the suburb as a cipher for what is perceived to be wrong in the urban and rural spheres.

\section{The realist suburb}

The historian Clapson (1998; 2003) belongs to what could be termed a nascent 'realist school' of contemporary history on the English suburb. Its roots are in the ground-breaking work of an earlier generation of American sociologists who saw in post-war suburbia nothing more than the rise of a modern, affluent and more mobile society (Gans 1967; Berger 1968; Webber 1970) as opposed to rural atavism (Glass 1989). Clapson's research suggests that there are grounds for thinking that English suburbanites of the post-war generation were not so different from their American counterparts (Clapson 2003, 52). What the theorists of the realist school have in common is a belief that the popularity of the suburbs as places where many people choose to live and work means they need to be taken 
seriously as a distinctive category of settlement, typically associated with liberal-democratic values such as individualism and lifestyle choice (Hubble 2006; Marshall 2006; White 2005; Steuer 2002). From this perspective sprawl is an expression of the power of suburban aspiration over urban living and a socio-economic success story in its own right (Gordon and Richardson 2000, Couch and Karecha 2006, Garreau 1992).

The realists have played an important part in establishing the suburbs as a credible field of academic study. From a theoretical perspective, however, they could be criticised for portraying the suburban as intrinsically progressive, in an emancipatory if not overtly political sense. This comes close to endorsing a deterministic view of the suburbs as the 'natural' product of advanced phases of urbanisation and therefore entitled to some higher moral legitimacy. Of course not all movements to the suburbs are out of choice, for example, the movement of miners to the suburbs following the restructuring of the coal industry from the 1950s onwards (Evans \& Larkham 2004) or the workingclass suburban life described by Hanley (2007). Despite this, the realists are probably most open to acknowledging suburban space as a distinctive field of social practice than other dominant representations because they are less likely to marginalise or mythologize them. Their difficulty lies in acknowledging the sheer number of ways in which people engage with the suburbs, not all of which may be consistent with the model of the suburbanite as a rational consumer or social aspirant.

\section{The idealist suburb}

Idealist representations of the suburb differ from the dystopian and realist in symbolising the possibility of reclaiming the lost (rural) past and through this redeeming the city and its population from degradation. The modern idealist tradition can trace its roots back to Ebenezer Howard's notion of the Garden City with its idea to combine the perfect mix of town and country qualities as a remedy to the dire social problems of the late nineteenth-century city and the cultural sterility and economic decline of the countryside (Miller 1992). With its emphasis on relatively low density housing, gardens and village greens, the idealist approach has been highly influential in the emergence of 'garden suburbs' and new towns both in the UK and throughout the world (Whitehand and Carr 1999). Whereas the Garden City movement targeted the human consequences of unregulated building, the economics of 'slumification' and urban unemployment, the New Urbanists in the United States argue that very low-density suburban living is environmentally and socially unsustainable (Calthorpe 1989; Calthorpe 1993; Tiesdell 2002). Despite their apparent differences, advocates of the New Urbanism share their idealism with the proponents of the Garden City. Both approaches contain strong communitarian prescriptions for social reform and put their faith in the planning process to affect social and environmental change.

Idealist representations of the suburb lend themselves to powerful cultural stereotyping in terms of the 'typical' family life. In the UK the highly popular 1970s BBC television situation comedy The Good Life was one of many which presented suburbia sentimentally but positively as a place where eccentricity prospered quietly behind the privet hedge and social discord could be resolved over a cup of tea and a biscuit. In the US the nostalgic suburban image of the television sitcom has been remorselessly parodied in films such as Pleasantville (1998) and American Beauty (1999). Both fantastic and dystopian images resonate throughout contemporary popular culture, as apparent in the US television series Desperate Housewives (Muzzio and Halper 2002). The appropriateness of these images to articulate the complex socio-economic and cultural diversity of contemporary suburbs is doubtful but it is undeniable that they constitute a powerful imaginary in which the suburban built environment is an important agent - the nature of that agency, however, remains relatively unexplored.

\section{Otherness}

The fourth and final assumption regarding suburban space, 'suburban otherness', refers to the tendency for the suburbs to be mythologized as places that exist somewhere else and are inhabited by people unlike ourselves. The idea of the suburb as the place where the waste of the city (both human and otherwise) is disposed of is not without basis in fact, as dirty trades such as leather tanning and institutions, including hospitals for the mentally ill and prisons, have traditionally been located beyond the urban periphery (Sinclair 2002). Mumford (not without irony) alludes to this tradition in one of his few relatively positive comments about the mid-twentieth century suburb.

...in the crowded, modern city, the first general exodus to a more desirable dwelling place in the country was the migration of the dead to the romantic Elysium of a suburban cemetery (Mumford 1961, 15).

Consistent with this view of the suburb as an earthly limbo Webster argues that it is the perceived insubstantiality of suburbia "devoid of cultural and aesthetic value so that the very absence of signification becomes a haunting presence" that has come to constitute the hermeneutic object (Webster 2000, 2). It is precisely this 'presence of absence', rendered as the heavily stylised vacuity of suburban life portrayed in films such as The Time Bandits (1980) or Edward Scissorhands (1991) which creates the dramatic potential for the fantastic events to unfold. Other suburban 
imaginaries feature in the psycho-geography of London's outer suburbs. Commenting on the life of the M25's executive villages Sinclair writes that:

The suburb is no longer a suburb, it's a denial of the motorway - on which it depends for its future survival (Sinclair 2002, 310).

Augé (1995) would characterise such locations as 'non-places' in which historical identity and centrality are gradually eroded by the social and technological forces that strip them of their local contexts. This theorisation renders suburban space perfectly textureless, defined by easy accessibility to nodes in what Castells (1989) refers to as the "space of flows". In contrast, Massey (2005) contends that such global geometries must be reproduced (practised) locally as well as vice versa and that, in reality, these totalising spatial productions are never complete. When suburban space is presumed to be unproblematic by discourses that seek to capture its essence once and for all they render it, by default, as marginal, ephemeral, inert and essentially other to everyday experience.

The assumption of suburban otherness can be identified in futurist representations of the suburb. The novelist J.G. Ballard has commented that he moved to the outer London suburb of Shepperton in the 1960s because he thought:

...the future isn't in the metropolitan areas of London. I want to go out to the new suburbs, near the film studios (The Guardian 2008b 12).

The association of the suburbs with creative high-technology industries fuels much of the current interest in decentralised development in locations such as Silicon Valley, California that constitute Garreau's 'edge cities'. The aspatial social networks and high disposable incomes of (some) people working and living in these environments has contributed to representations of the suburb as a non-place. However, they also serve as reminders that the suburbs are as much about commerce as about consumption, and that suburban life includes poverty and environmental pollution as well as wealth and clean air (Pellow and Park 2002).

The fecundity of vocabulary for contemporary suburban built environments is impressive. A selection includes: 'outtowns' (Goldberger 1987), 'technoburbs' ( Fishman 1987), 'exopolis' (Soja 2000), 'superburbs' (Bourne 1996, 173), 'ethnoburbs' (Li 1998), 'edgeless cities' (Lang 2003), 'Zoomburbs' (Hayden 2004) and 'boomburbs' (Lang and LeFurgy 2007). These settlement forms, associated with radical decentralisation and the expansion of urban 'sprawl', have been classified by Phelps et al (2006) as the 'post-suburban'. These interesting suburban developments certainly merit serious academic consideration. However, we suggest that this multiplicity of neologisms indicates a need for more focused research into suburban space. In these futurist representations of the suburbs, novelty is perpetual; there is no time for a past to accumulate at locations where social and economic energy will soon move onto the next frontier. Ironically, this renders them incapable of adaptation or change since such 'strange' built forms are devoid of historical continuity with existing (or pre-existing) built environments and landscapes. In the absence of a more substantive conceptual framework, too exclusive a focus on suburban novelty implies a base representation of suburban space as tabula rasa and therefore elides the question of suburban persistence in time.

\section{Conclusions}

The reconsideration of the theoretical basis of suburban studies advanced in this article has been prompted by research into Greater London's suburban town centres as part of the ongoing Towards Successful Suburban Town Centres project (Vaughan 2006; Griffiths, et al 2008; Vaughan et al 2009). The wide-ranging literature review designed to lay the groundwork for this research clearly showed that while both urban and rural studies have long thrived, suburban studies are generally neglected as a distinctive field and the inherent needs and problems of suburban living remain unaddressed. Scholars researching suburbia in the framework of different disciplines still have no easy overview of what the different areas of their subject have in common. There is, of course, no question that the suburbs do exist. Increasingly they are a theme of universal significance, implicated in the growth of globalised 'world cities' and the rapid development of the built environment in emerging economies. However, the argument advanced in this article is that until the agency of suburban space as a distinctive domain of social organisation is acknowledged, then the notion of the 'suburb' remains too epistemologically fragile to carry the burden of representation that it currently bears.

The consequence of this fragility is that research in the field of suburban studies risks being undermined by an enduring legacy of widely-held assumptions regarding the 'essential' nature of the suburb. Yet such suburban imaginations tend to be derived from historically particular instances, rather than from a consideration of the type of generic problem that the suburb represents. This article, therefore, has sought to make the case for a theoretical consideration of suburban space on its own terms as a specific and complex field of social practice. Rather than 
tacitly conceiving of suburban space as formless, timeless and 'other', it is equally possible to think of it as dynamic, persistent and familiar. We propose that the significance of suburban theory lies in its potential to undermine onedimensional approaches to the built environment by refocusing attention on the manifold social complexities that emerge from the differentiation of its spatial-temporal form.

\section{Acknowledgements}

The authors wish to thank the referees for their helpful comments on a previous draft of this article. This article was written with the support of a 36 months' study of suburban town centres funded by the EPSRC (Engineering and Physical Sciences Research Council), start date 01/10/06. EPSRC reference EP/D06595X/1.

\section{References}

Ackroyd P 2000 London: the biography Chatto \& Windus, London,

Anderson K 2006 Introduction: After Sprawl: Post-Suburban Sydney in Anderson K, Dobson R, Allon F and Neilson B eds Post-Suburban Sydney: The City in Transformation, Centre for Cultural Research, University of Western Sydney, Parramatta, Sydney

Archer J 2005 Architecture and Suburbia, From English Villa to American Dream House 1690-2000, Minneapolis, University of Minnesota Press

Augé M 1995 Non-places: introduction to anthropology of supermodernity trans. J Howe London, Verso

Berger B M 1968 Suburbia and the American Dream in Fava S F ed Urbanism in World Perspective: A Reader New York, Cromwell 434-44

Bourne L S 1996 Reinventing the Suburbs: Old Myths and New Realities Progress in Planning 463 163-84

Bullard RD, Johnson GS and Torres A, O. Eds 2000 Sprawl City: Race, Politics, and Planning in Atlanta, Island Press, Washington, D.C.

Burgess E W 1967/1925 The Growth of the City: An Introduction to a Research Project in Park R E Burgess E W and McKenzie R D The City University of Chicago Press, Chicago 47-62

Calthorpe P 1989 Pedestrian Pockets: new strategies for suburban growth in Kelbaugh D ed The Pedestrian Pocket Book: a New Suburban Design Strategy Princeton University Press, Princeton, New Jersey

Calthorpe P 1993 The Next American Metropolis: Ecology, Community and the American Dream Princeton Architectural Press, New York

Cannadine D 1977 Victorian cities how different? Social History 2 114-146

Carter H 1983 An Introduction to Urban Historical Geography London Edward Arnold

Castells M 1989 The Informational City: information technology, economic restructuring, and the urban-regional process Blackwell, Oxford

Castells M 1996 The rise of the network society Blackwell, Cambridge, Mass

Clapson M 2003 Suburban Century: social change and urban growth in England and the USA Berg, Oxford

Clapson M 1998 Invincible Green Suburbs, Brave New Towns: social change and urban dispersal in post-war England Manchester University Press, Manchester,

Connell J 1974 The Metropolitan Village: Spatial and Social Processes in Discontinuous Suburbs. In Johnson J H ed Suburban Growth: Geographical Processes at the Edge of the Western City John Wiley and Sons, London 77-100

Conzen M 1960 Alnwick, Northumberland: a study in town-plan analysis Transactions and Papers (Institute of British Geographers) 27 3-4

Couch C and Karecha J 2006 Controlling Urban Sprawl: Some experiences from Liverpool Cities 23 353-363

Dennis R 2008 Cities in Modernity: Representations and Productions of Metropolitan Space, 1840-1930 Cambridge University Press, Cambridge

Duany A Plater-Zyberk E and Speck J 2000 Suburban Nation: The Rise of Sprawl and the Decline of the American Dream North Point Press, New York

Dyos H J 1977/1961 Victorian suburb: a study of the growth of Camberwell Leicester University Press, Leicester

Evans G and Larkham PJ 2004 Designing and living in a new industrial suburb: experiences in the Cannock Chase coalfield from the 1950s to the 1970s Environment and Planning B 31 673-691

Fishman R 1987 Bourgeois Utopias: The Rise and Fall of Suburbia Basic Books, New York

Gans H J 1967 The Levittowners The Penguin Press, London

Garreau J 1992 Edge City: life on the new frontier Anchor Books, London

Giddens A 1984 The Constitution of Society - Outline of the Theory of Structuration, Polity Press, Cambridge

Giles J 2004 The Parlour and the Suburb: domestic identities, class, femininity and modernity Berg, Oxford

Glass R 1989 Urban Sociology in Glass R ed Clichés of Urban Doom and Other Essays Blackwell, Oxford

Goldberger P 1987 When suburban sprawl meets upward mobility New York Times 26 July, 14 
Goldsworthy V 2004 The Love that Dares not Speak its Name: Englishness and Suburbia in Rogers D and MacLeod J eds Revisions of Englishness Manchester University Press, Manchester, 95-106

Gordon P and Richardson H W 2000 Critiquing Sprawl's Critics Cato Institute, Washington D C

Griffiths S 2009 Persistence and Change in the Spatio-temporal Description of Sheffield Parish 1770-1910 in Koch D Marcus $\mathbf{L}$ and Steen $\mathbf{J}$ eds Proceedings of the 7th International Space Syntax Symposium KTH Royal Institute of Technology, Stockholm

Griffiths S Vaughan L Haklay M and Jones K E 2008 The sustainable suburban high street: themes and approaches Geography Compass 2 1155-1188

Gwilliam M Bourne C Swain C and Prat A 1999 Sustainable Renewal of Suburban Areas York: Joseph Rowntree Foundation

Hägerstrand T 1967 Innovation diffusion as a spatial process / translation by Allan Pred and Greta Haag University of Chicago Press, Chicago

Hägerstrand T 1982 The Impact of Social Organization and Environment upon the Time-use of Individuals and Households, in Bourne L S ed Internal Structure of the City: Readings on Urban Form, Growth and Policy Oxford University Press, Oxford and New York 118-124

Hall P and Pain K 2006 The polycentric metropolis: learning from mega-city regions in Europe Earthscan, London

Hanley L 2007 Estates: an intimate history Granta Books London

Hapgood L 2005 Margins of Desire: The suburbs in fiction and culture 1880-1925 Manchester: Manchester University Press

Harris R 2004 Creeping conformity : how Canada became suburban, 1900-1960 University of Toronto

Harris R 1996 Unplanned suburbs : Toronto's American tragedy, 1900 to 1950 Baltimore London : Johns Hopkins University Press

Harris R and Larkham PJ 1999 Changing Suburbs: Foundation, Form and Function E \& FN Spon, London Harris R and Lewis R 2001 The Geography of North American Cities and Suburbs, 1900-1950: A New Synthesis Journal of Urban History 27 262-292

Harvey D 1989 The Urban Experience Baltimore; London: Johns Hopkins University Press

Hayden D 2004 A Field Guide to Sprawl W Norton and Company, New York

Hillier B 2008 Space and Spatiality: what the built environment needs from social theory Building Research \& Information $36216-230$

Hillier B and Netto V 2002 Society seen through the prism of space: outline of a theory of society and space Urban Design International, 7 3-4 181-203

Hinchcliffe T 2005 Elusive suburbs endless variation Journal of Urban History 316 899-906

Hubbard P J 2006 The City Routledge Taylor and Francis Group, London and New York

Hubble N 2006 Naked Democracy and Suburban Pastoral: Socio-Cultural Perspectives on the Suburbs. Presentation to workshop on the Principles of Zero Carbon Emission Neighbourhoods in the Contemporary Suburban Context

Hunt T 2004 Building Jerusalem: The Rise and Fall of the Victorian City Weidenfeld and Nicholson, London

ITC (Independent Transport Commission) 2004 Suburban Future ITC, London

Jackson A A 1973 Semi-detached London: suburban development, life and transport, 1900-39 Allen and Unwin, London

Jackson K T 1985 Crabgrass frontier : the suburbanization of the United States Oxford University Press, New York

Kelly B M 1993 Expanding the American Dream: Building and Rebuilding Levittown, State University of New York Press, New York

Kruse M K 2005 White Flight: Atlanta and the Making of Modern Conservatism, Princeton University Press, New Jersey USA and Oxford UK

Lang R E 2003 Edgeless cities: exploring the elusive metropolis Brookings Institution, Washington D C

Lang R and LeFurgy J B 2007 Boomburbs: the rise of America's accidental cities Brookings Institution Press, Washington, DC

Lefebvre H 1991 The Production of Space (originally in French, 1974 as Production de l'espace) Nicholson-Smith D trans Basil Blackwell Oxford

Li W 1998 Anatomy of a New Ethnic Settlement: The Chinese Ethnoburb in Los Angeles Urban Studies 353 479501

Marsh M 1990 Suburban Lives Rutgers University Press, New Brunswick and London

Marshall S 2006 The Emerging "Silicon Savannah": From Old Urbanism to New Suburbanism Built Environment 32 267-280

Massey D B 2005 For Space Sage, London

Massey D S Denton N A 1993 American Apartheid: Segregation and the Making of the Underclass, Harvard University Press, Cambridge MA USA, London UK

Masucci A P and Rogers G J 2008 The Network of Commuters in London Physica A 3873871

McLuhan H M 2002/1951 The Mechanical Bride: folklore of industrial man Corte Madera Ginko Press, California 
McManus R and Ethington P J 2007 Suburbs in transition: new approaches to suburban history Urban History 342 317-337

Miller M 1992 Raymond Unwin: Garden Cities and Town Planning Continuum International Publishing Group, Leicester

Mumford L 1940 The Culture of Cities Secker and Warburg, London

Mumford L 1961 The City in History Secker and Warburg, London

Muzzio D and Halper T 2002 Pleasantville? The Suburb and its Representation in American Movies Urban Affairs Review 374 543-574

Nairn I 1955 Outrage Architectural Press London

Nairn I. 1956 Counter-Attack against Subtopia Architectural Press , London

Nicolaides B and Wiese A 2006 The Suburb Reader Routledge New York

Nicolaides B 2002 My Blue Heaven, Life and Politics in the Working-Class Suburbs of Los Angeles, 1920-1965 University of Chicago Press, Chicago, London

Pacione M 2005 Urban geography: a global perspective $2^{\text {nd }}$ ed Routledge, London

Pellow D N and Sun-Hee Park L 2002 The Silicon Valley of dreams: environmental injustice, immigrant workers, and the high-tech global economy New York University Press, New York

Phelps N A Parsons N Ballas D and Dowling D 2006 Post-suburban Europe: planning and politics at the margins of Europe's capital Palgrave Macmillan, Basingstoke

Phillips D, Davis C and Ratcliffe P 2007 British Asian narratives of urban space Transactions of the Institute of British Geographers, 00032, 217-235

Polasky J 2001 Transplanting and Rooting Workers in London and Brussels: A Comparative History The Journal of Modern History 73 528-560

Pred A 1990 Making Histories and Constructing Human Geographies Westview Press, Boulder

Putnam R D 2000 Bowling Alone: the collapse and revival of American community Simon and Schuster London; New York

Riesman D 1950 The Lonely Crowd: a study of the changing American character with R Denney and N Glazer Yale University Press, New Haven

Sieverts T 2003 Cities Without Cities: an interpretation of the Zwischenstadt Spon Press, London

Silverstone R 1997 Visions of Suburbia Routledge, London

Sinclair I 2002 London Orbital: A Walk around the M25 Granta Books, London

Soja E W 1990 Postmodern geographies : the reassertion of space in critical social theory Verso, London

Soja E W 2000 Postmetropolis : critical studies of cities and regions Blackwell, Oxford

Spiers M 1976 Victoria Park, Manchester: a nineteenth-century suburb in its social and administrative context Chetham Society, Manchester

SSTC (Towards Successful Suburban Town Centres Project) 2006-09 University College London. www.sstc.ucl.ac.uk/profiler, accessed 30/03/09

Stilgoe J R 1989 Borderland: origins of the American suburb 1820-1939 Yale University Press, New Haven

Steur M 2002 Urban Sprawl: A Philosophical Investigation London School of Economics London

The Daily Telegraph 2006 Going down in the world, http://www.telegraph.co.uk/property/3349707/Goingdown-in-the-world.html. Accessed 30/03/09

The Guardian 2008a A sign of the times in Bankruptsville, USA. 14/06/08 http://www.guardian.co.uk/business/2008/jun/14/subprimecrisis.useconomy. Accessed 17/08/09

The Guardian 2008b The Guardian 14th June 2008, Review Section 12-13.

Thorns D C 1972 Suburbia London: MacGibbon and Kee

Tiesdell S 2002 The New Urbanism and English Residential Design Guidance a Review Journal of Urban Design 7 353-376

Urban Taskforce 2005 Towards a Strong Urban Renaissance Urban Taskforce, London

Vaughan L 2006 Making connections: the case of Borehamwood Built Environment: special issue on sustainable suburbs ed Nicholas Falk 32 281-297

Vaughan, L, Jones, C E, Griffiths, S and Haklay, M 2009 The Spatial Signature of Suburban 'Active' Centres in Koch D Marcus L and Steen J eds Proceedings of the Seventh International Space Syntax Symposium KTH Royal Institute of Technology Stockholm

Warner S B 1978/1962 Streetcar suburbs the process of growth in Boston 1870-1900 2nd ed Harvard University Press, London

Webber M 1970 Order in diversity: community without propinquity in Wingo L ed Cities and Space: The Future Use of Urban Land John Hopkins Press, Baltimore

Webster R ed 2000 Expanding suburbia: reviewing suburban narratives Berghahn Books, New York

White J 2005 Trouble in Arcadia: The London Suburbs, 1840 to the Present Day Successful Suburbs, Paper presented to Successful Cities Conference 3rd February 2005 Arts Depot, Finchley, London Borough of Barnet London

Whitehand J W R and Carr C M H 1999 England's Garden Suburbs: development and change in Larkham P J and Harris R eds Changing Suburbs: Foundation, Form and Function Routledge, London 76-110 
Whitehand J W R and Carr C M H 2001 Twentieth-Century Suburbs: a morphological approach Routledge, London

Whitehand J W R and Morton N J 2003 Fringe belts and the recycling of urban land: an academic concept and planning practice Environment and Planning B: Planning and Design 30 829-839

Whitehand J W R, Larkham P J and Jones A N 1992 The Changing Suburban Landscape in Post-war England in Whitehand J W R and Larkham P J eds Urban Landscapes: International Perspectives Routledge, London 227-264

Whyte W H 1956 The Organization Man Simon and Schuster, New York

Wiese A 2004 Places of their own: African American suburbanization in the twentieth century University of Chicago Press, Chicago London

Williams R 1975 The country and the city Paladin, St. Albans

Young M and Willmott P 1962/1957 Family and Kinship in East London Penguin, Harmondsworth, Middlesex 